\title{
1 Sustained Ranavirus outbreak causes mass-mortality and morbidity 2 in imperiled amphibians.
}

3

Arik M. Hartmann ${ }^{1} *$, Max L. Maddox ${ }^{2}$, Robert J. Ossiboff ${ }^{3}$, \& Ana V. Longo ${ }^{1}$

${ }^{1}$ Department of Biology, College of Liberal Arts and Sciences, University of Florida, Gainesville, FL 32611

${ }^{2}$ Department of Wildlife Ecology and Conservation, College of Agriculture and Life Sciences, University of Florida, Gainesville, FL 32611

${ }^{3}$ Department of Comparative, Diagnostic, and Population Medicine, College of Veterinary Medicine, University of Florida, Gainesville, FL 32610

*Corresponding author e-mail: arikhartmann@ufl.edu

Keywords: salamander, Frog virus 3, gopher frog, striped newt, amphibian mortality, ranavirus

\section{Abstract}

A persistent two-month long outbreak of Ranavirus in a natural community of amphibians contributed to a mass die-off of gopher frog tadpoles (Lithobates capito) and severe disease in striped newts (Notophthalmus perstriatus) in Florida. Ongoing mortality in L. capito and signs in N. perstriatus continued for five weeks after the first observation. Hemorrhagic disease and necrosis were diagnosed from pathological examination of L. capito tadpoles. We confirmed detection of a Frog Virus 3 (FV3)like Ranavirus via quantitative PCR in all species. Our findings highlight the susceptibility of these species to $R v$ and the need for long-term disease surveillance during epizootics.

\section{Introduction}

Emerging wildlife diseases are increasingly associated with amphibian mass mortalities and global amphibian declines (Rachowicz et al. 2006), and have led to heightened awareness and surveillance of amphibian pathogens. Iridoviruses in the genus Ranavirus $(R v)$ and the amphibian chytrid fungus Batrachochytrium dendrobatidis $(B d)$ are two emerging pathogens that are widely associated with amphibian mass mortality events (Miller et al. 2011; Fisher and Garner 2020). Outbreaks often result in high mortality of sensitive life stages or species, while tolerant species and life stages can serve as pathogen reservoirs (Gray et al. 2009; Schloegel et al. 2010). In the United States (US), pathogenmediated mass mortalities and declines have been primarily recorded in larval amphibians in the northern and western regions of the country (Green et al. 2002). The Southeastern Coastal Plain of the US harbors the highest diversity of amphibians in North America (Noss et al. 2015), and although $R v$ and $B d$ have been detected in the region, reports of mortality events and their effects are lacking.

We report here the findings of a two-month long outbreak of $R v$ in a natural amphibian community using pathological examination of moribund tadpoles and confirmed pathogen presence via quantitative PCR 
(qPCR). We present the first report of $R v$-induced mass mortality and morbidity in two Coastal Plain endemic amphibians: the gopher frog (Lithobates capito) and the striped newt (Notophthalmus perstriatus). Both species have histories of range-wide declines (Jensen and Richter 2005; Farmer et al. 2017), and are listed by the Florida Fish and Wildlife Conservation Commission (FWC) as species of greatest conservation need (FWC 2019).

We first observed mass-mortality of L. capito tadpoles on 23 January 2021 at One Shot Pond, in OrdwaySwisher Biological Station (OSBS), Putnam County, Florida. We observed ongoing die-offs during a second visit to the pond on 7 March 2021. One Shot Pond is a semi-permanent fishless wetland that provides important breeding habitat for 16 amphibian species, and is one of few wetlands at OSBS that supports both L. capito and N. perstriatus populations (LaClaire 1995; Johnson 2002).

During both surveys, we captured amphibians by dipnet or hand and stored them in individual plastic bags for processing. Each amphibian was examined to confirm species identification and detect gross symptoms of disease. For pathogen sampling, we swabbed the oral disc and vent of tadpoles following procedures established by (Gray et al. 2012) and swabbed caudates and post-metamorphic anurans following standard protocols for amphibian disease sampling (Hyatt et al. 2007). We collected 19 dead and moribund L. capito tadpoles for histopathological analysis and fixed them in $70 \%$ ethanol. We estimated over 500 L. capito tadpoles at Gosner stages 28-31 (Gosner 1960) had died between the two events, and most living tadpoles of the same age class showed symptoms of $R v$ infection, such as edema and hemorrhage (Fig. 1A-B). We did not observe mortality in N. perstriatus, however all newts exhibited erythema, hemorrhage, or necrosis (Fig. 1C-D). L. capito tadpoles at Gosner stages 23-25 (hatchlings) were abundant and did not show any clinical signs of infection, nor did any southern cricket frogs (Acris gryllus) around the pond perimeter.

All 19 ethanol-fixed tadpoles were briefly decalcified in $0.5 \mathrm{M}$ ethylenediamine tetraacetate acid (EDTA), $\mathrm{pH} 8.0$ for $\sim 24 \mathrm{~h}$ before sagittal sectioning and routine histopathologic processing and staining. Microscopic findings included necrosis of the genal glomeruli and interstitium (16/19 tadpoles, Fig. 2A), spleen (3/19 tadpoles, Fig. 2B), and liver (2/19 tadpoles) with cutaneous and subcutaneous hemorrhage (4/19 tadpoles) and vascular inflammation (2/19 tadpoles). In a subset of tadpoles (8/19), there were basophilic to amphophilic, cytoplasmic viral inclusion bodies present in hepatocytes (Fig. 2C). Swab samples were tested for FV3-like $R v$ and $B d$ using qPCR assays following protocols established by (Allender et al. 2013) and (Boyle et al. 2004), respectively. We mostly detected severe $R v$ infections in $L$. capito tadpoles, paedomorphic and recently metamorphosed $N$. perstriatus, and low to moderate infections in adult A. gryllus from both sampling events (Fig. 3). Species with disease signs had a higher proportion of individuals with intense $R v$ infections $\left(>10^{5}+\right)$. We detected $B d$ only in 10 A. gryllus, nine of which were also co-infected with $R v$ (Table 1$)$.

$R v$ outbreaks can impact amphibian population dynamics by dampening recruitment, and pathogen persistence in the environment can negate recruitment entirely (Petranka et al. 2007), facilitating the local extinction of rare species (Earl et al. 2016). To our knowledge, reports of $R v$ outbreaks in natural populations of $L$. capito have not been published, but experimental infections of $L$. capito resulted in $>90 \%$ mortality of tadpoles (Hoverman et al. 2011). Our observations show similar susceptibility under natural conditions, providing support for disease-related declines. Ongoing die-offs of tadpoles suggest that older cohorts may serve as vectors to younger cohorts through viral shedding, direct contact, or necrophagy (Harp and Petranka 2006; Peace et al. 2019).

80 As a multi-host pathogen of ectotherms, $R v$ outbreaks in amphibians can spread to the wider ectothermic 
gopher tortoises (Gopherus polyphemus) (Johnson et al. 2008; Cozad et al. 2020), and Rv outbreaks in chelonians have been attributed to pathogen spillover from sympatric amphibians (Brunner et al. 2015). $L$. capito are closely associated with G. polyphemus and are one nine amphibians known to cohabitate in tortoise burrows (Jackson and Milstrey 1989). At One Shot Pond there are >10 G. polyphemus burrows within 30 meters of the pond, and we have observed L. capito calling from burrow entrances. It is possible that $R v$ outbreaks can spill over to G. polyphemus and other ectothermic commensals by adult $L$. capito moving between ponds and burrows during breeding.

In contrast to $L$. capito, natural populations of $N$. perstriatus have not been extensively surveyed for disease, but $R v$ is a common pathogen of the closely related and sympatric eastern newt ( $N$. viridescens) (Rothermel et al. 2016). N. perstriatus have experienced enigmatic declines and extirpations throughout their range in Florida and Georgia (Farmer et al. 2017), and repatriation efforts have been unsuccessful (Means et al. 2017). Experimental $R v$ exposure of captive reared $N$. perstriatus resulted in high mortality of aquatic and recently metamorphosed stages (Means et al. 2016). Our observations suggest that high pathogen pressure could result in $N$. perstriatus declines, and persistent disease may be inhibiting the recovery of the species. Our results provide evidence of disease-related risks in populations, a missing element that can strengthen the petition to list N. perstriatus under the Endangered Species Act (USFWS 98 2011;2016).

In species with complex life histories, densities and life-stages fluctuate seasonally and can result in recurring epidemics and pathogen persistence through transmission between life stages (Brunner et al. 2004). N. perstriatus have complex life history strategies that include facultatively paedomorphic and triphasic developmental routes, and spend three of five life stages in water (Johnson 2002). These findings support our ongoing studies where we have found that paedomorphic life stages are more susceptible to $R v$ and experience higher disease burdens than other life stages (Hartmann et al. in preparation). We hypothesize that pathogen pressure in aquatic stages is density-dependent. Sustained $R v$ infections in metamorphosing newts may allow them to act as intraspecific reservoirs when they return to ponds as adults to breed. Long-term $R v$ persistence may select against the paedomorphic developmental route in $N$. perstriatus, which would have profound effects on population structure and annual recruitment as paedomorphic stages undergo accelerated maturation and reproduction (Dodd 1993).

Our findings also identify tolerant hosts that may act as reservoirs to more susceptible species (Brunner et al. 2004). A. gryllus are often the most abundant amphibian at ponds within OSBS (personal observation), occupy a variety of habitats, and can easily disperse between water bodies within OSBS (Dodd 1996). Because we did not find disease signs in A. gryllus, we hypothesize that high tolerance may allow $R v$ to persist in these hosts. Estimating dispersal rates for this species can help us predict pathogen spread across habitat types and amphibian assemblages.

116 Despite the diversity of amphibians in Florida and history of recent declines, reports of amphibian die117 offs in the state are rare and few have been published (Landsberg et al. 2013). Although both $R v$ and $B d$ have been detected, prior reports of mass mortality events in Florida have been attributed to Perkinsea parasites (Isidoro-Ayza et al. 2017). Here we provide the first report of a mass mortality event attributed to $R v$ in $L$. capito. The confirmation of $R v$ infection, resulting disease, and mass mortality pose major concerns for Florida's amphibian and reptile populations, particularly specialist species with limited ranges. Both $L$. capito and $N$. perstriatus are habitat specialists in Florida threatened by habitat loss (Enge et al. 2014), and it is in the interest of state and federal wildlife agencies to further explore the implications that emerging pathogens have on management strategies. Future work must consider the role of emerging pathogens in past and continued amphibian declines. Current conservation plans must include pathogen mitigation strategies to ensure population survival and success of repatriation programs. 


\section{Acknowledgements}

We thank B. Folt (USGS) and L. Brendel (UF) for helping with sample collection, and the staff of the Histology Laboratory at University of Florida's College of Veterinary Medicine for slide preparation. We also thank Andy Rappe and the staff at the Ordway-Swisher Biological Station for facilitating this work. Sampling was carried out under the permission of the Florida Fish and Wildlife Conservation Commission (FWC-LSSC-17-00031B) and the University of Florida's Institutional Animal Care and Use Committee (\#201810502). We thank members of the Longo Lab and S. Cassidy for their feedback on previous drafts of this manuscript.

\section{References}

Allender MC, Bunick D, Mitchell MA (2013) Development and validation of TaqMan quantitative PCR for detection of frog virus 3-like virus in eastern box turtles (Terrapene carolina carolina). Journal of Virological Methods 188:121-125. https://doi.org/10.1016/j.jviromet.2012.12.012

Boyle D, Boyle D, Olsen V, Morgan J, Hyatt A (2004) Rapid quantitative detection of chytridiomycosis (Batrachochytrium dendrobatidis) in amphibian samples using real-time Taqman PCR assay. Diseases of Aquatic Organisms 60:141-148. https://doi.org/10.3354/dao060141

Brenes R, Gray MJ, Waltzek TB, Wilkes RP, Miller DL (2014) Transmission of ranavirus between ectothermic vertebrate hosts. PLoS ONE 9:e92476. https://doi.org/10.1371/journal.pone.0092476

Brunner JL, Schock DM, Davidson EW, Collins JP (2004) Intraspecific reservoirs: complex life history and the persistence of a lethal ranavirus. Ecology 85:560-566. https://doi.org/10.1890/02-0374

Brunner JL, Storfer A, Gray MJ, Hoverman JT (2015) Ranavirus Ecology and Evolution: From Epidemiology to Extinction. In: Ranaviruses. Springer, Cham, pp 71-104

Cozad RA, Norton TM, Aresco MJ, Allender MC, Hernandez SM (2020) Pathogen surveillance and detection of ranavirus (frog virus 3 ) in translocated gopher tortoises (Gopherus polyphemus). Journal of Wildlife Diseases 56:679. https://doi.org/10.7589/2019-02-053

Dodd CK (1993) Cost of living in an unpredictable environment: the ecology of striped newts Notophthalmus perstriatus during a prolonged drought. Copeia 1993:605. https://doi.org/10.2307/1447221

Dodd CK (1996) Use of terrestrial habitats by amphibians in the sandhill uplands of north-central Florida. Alytes 14:42-52

Earl JE, Chaney JC, Sutton WB, Lillard CE, Kouba AJ, Langhorne C, Krebs J, Wilkes RP, Hill RD, Miller DL, Gray MJ (2016) Ranavirus could facilitate local extinction of rare amphibian species. Oecologia 182:611-623. https://doi.org/10.1007/s00442-016-3682-6

Enge KM, Farmer AL, Mays JD, Castellón TD, Hill PE, Moler PE (2014) Survey of winter-breeding amphibian species. Florida Fish and Wildlife Conservation Commission, Fish and Wildlife Research Institute, Lovett E. Williams, Jr. Wildlife Research Laboratory, Gainesville, Florida, USA

Farmer AL, Enge KM, Jensen JB, Stevenson DJ, Smith LL (2017) A range-wide assessment of the status and distribution of the striped newt (Notophthalmus perstriatus). Herpetological Conservation and Biology 12:585-598 
166

167

168

169

170

171

172

173

174

175

176

177

178

179

180

181

182

183

184

185

186

187

188

189

190

191

192

193

194

195

196

197

198

199

200

201

202

Fisher MC, Garner TWJ (2020) Chytrid fungi and global amphibian declines. Nature Review Microbiology 18:332-343. https://doi.org/10.1038/s41579-020-0335-x

Gosner KL (1960) A simplified table for staging anuran embryos and larvae with notes on identification. Herpetologica 16:183-190

Gray M, Miller D, Hoverman J (2009) Ecology and pathology of amphibian ranaviruses. Diseases of Aquatic Organisms 87:243-266. https://doi.org/10.3354/dao02138

Gray M, Miller D, Hoverman J (2012) Reliability of non-lethal surveillance methods for detecting ranavirus infection. Diseases of Aquatic Organisms 99:1-6. https://doi.org/10.3354/dao02436

Green DE, Converse KA, Schrader AK (2002) Epizootiology of sixty-four amphibian morbidity and mortality events in the USA, 1996-2001. Annals of the New York Academy of Sciences 969:323-339. https://doi.org/10.1111/j.1749-6632.2002.tb04400.x

Harp EM, Petranka JW (2006) Ranavirus in wood frogs (Rana sylvatica): potential sources of transmission within and between ponds. Journal of Wildlife Diseases 42:307-318. https://doi.org/10.7589/0090-3558-42.2.307

Hoverman JT, Gray MJ, Haislip NA, Miller DL (2011) Phylogeny, life history, and ecology contribute to differences in amphibian susceptibility to ranaviruses. EcoHealth 8:301-319. https://doi.org/10.1007/s10393-011-0717-7

Hyatt A, Boyle D, Olsen V, Boyle D, Berger L, Obendorf D, Dalton A, Kriger K, Hero M, Hines H, Phillott R, Campbell R, Marantelli G, Gleason F, Colling A (2007) Diagnostic assays and sampling protocols for the detection of Batrachochytrium dendrobatidis. Diseases of Aquatic Organisms 73:175-192. https://doi.org/10.3354/dao073175

Isidoro-Ayza M, Lorch JM, Grear DA, Winzeler M, Calhoun DL, Barichivich WJ (2017) Pathogenic lineage of Perkinsea associated with mass mortality of frogs across the United States. Scientific Reports 7:10288. https://doi.org/10.1038/s41598-017-10456-1

Jackson DR, Milstrey EG (1989) The fauna of gopher tortoise burrows. Florida Game and Fresh Water Fish Commission Nongame Wildlife Program, Gopher tortoise relocation symposium proceedings

Jensen JB, Richter SC (2005) Rana capito, Gopher Frogs. In: Amphibian Declines: The Conservation Status of United States Species. University of California Press, Berkeley, California, pp 536-538

Johnson AJ, Pessier AP, Wellehan JFX, Childress A, Norton TM, Stedman NL, Bloom DC, Belzer W, Titus VR, Wagner R, Brooks JW, Spratt J, Jacobson ER (2008) Ranavirus infection of freeranging and captive box turtles and tortoises in the United States. Journal of Wildlife Diseases 44:851-863. https://doi.org/10.7589/0090-3558-44.4.851

Johnson SA (2002) Life history of the striped newt at a north-central Florida breeding pond. Southeastern Naturalist 1:381-402. https://doi.org/10.1656/1528-7092(2002)001[0381:LHOTSN]2.0.CO;2

LaClaire LV (1995) Vegetation of selected upland temporary ponds in north and north-central Florida. Bulletin of the Floirda Museum of Natural History 38:69-96 
203

204

205

206

207

208

209

210

211

212

213

214

215

216

217

218

219

220

221

222

223

224

225

226

227

228

229

230

231

232

233

234

235

236

237

238

239

240

241

Landsberg J, Kiryu Y, Tabuchi M, Waltzek T, Enge K, Reintjes-Tolen S, Preston A, Pessier A (2013) Coinfection by alveolate parasites and frog virus 3-like ranavirus during an amphibian larval mortality event in Florida, USA. Diseases of Aquatic Organisms 105:89-99. https://doi.org/10.3354/dao02625

Means RC, Means RPM, Beshel M, Mendyk R, Hill P, Hoffman M, Reichling S, Summerford B (2017) A Conservation Strategy for the Imperiled Western Striped Newt in the Apalachicola National Forest, FL

Means RC, Means RPM, Beshel M, Mendyk R, Hill P, Summerford B, Elkert A, Gray MJ, Miller DL (2016) A Conservation Strategy for the Imperiled Western Striped Newt in the Apalachicola National Forest, FL

Miller D, Gray M, Storfer A (2011) Ecopathology of ranaviruses infecting amphibians. Viruses 3:23512373. https://doi.org/10.3390/v3112351

Noss RF, Platt WJ, Sorrie BA, Weakley AS, Means DB, Costanza J, Peet RK (2015) How global biodiversity hotspots may go unrecognized: lessons from the North American Coastal Plain. Diversity and Distributions 21:236-244. https://doi.org/10.1111/ddi.12278

Peace A, O'Regan SM, Spatz JA, Reilly PN, Hill RD, Carter ED, Wilkes RP, Waltzek TB, Miller DL, Gray MJ (2019) A highly invasive chimeric ranavirus can decimate tadpole populations rapidly through multiple transmission pathways. Ecological Modelling 410:108777. https://doi.org/10.1016/j.ecolmodel.2019.108777

Petranka JW, Harp EM, Holbrook CT, Hamel JA (2007) Long-term persistence of amphibian populations in a restored wetland complex. Biological Conservation 138:371-380. https://doi.org/10.1016/j.biocon.2007.05.002

Rachowicz LJ, Knapp RA, Morgan JAT, Stice MJ, Vredenburg VT, Parker JM, Briggs CJ (2006) Emerging infectious disease as a proximate cause of amphibian mass mortality. Ecology 87:1671-1683. https://doi.org/10.1890/0012-9658(2006)87[1671:EIDAAP]2.0.CO;2

Rothermel BB, Miller DL, Travis ER, McGuire JLG, Jensen JB, Yabsley MJ (2016) Disease dynamics of red-spotted newts and their anuran prey in a montane pond community. Diseases of Aquatic Organisms 118:113-127. https://doi.org/10.3354/dao02965

Schloegel LM, Ferreira CM, James TY, Hipolito M, Longcore JE, Hyatt AD, Yabsley M, Martins AMCRPF, Mazzoni R, Davies AJ, Daszak P (2010) The North American bullfrog as a reservoir for the spread of Batrachochytrium dendrobatidis in Brazil: The North American bullfrog as a reservoir for the spread of an amphibian pathogen. Animal Conservation 13:53-61. https://doi.org/10.1111/j.1469-1795.2009.00307.x

U.S. Fish and Wildlife Service (USFWS) (2011) Endangered and threatened wildlife and plants; 12month finding on a petition to list the Striped Newt as threatened

U.S. Fish and Wildlife Service (USFWS) (2016) Endangered and threatened wildlife and plants; review of native species that are candidates for listing as endangered or threatened; annual notice of findings on resubmitted petitions; annual description of progress on listing actions

(2019) Florida State Wildlife Action Plan. Florida Fish and Wildlife Conservation Commission 
bioRxiv preprint doi: https://doi.org/10.1101/2021.1015.464511. this version posted October 15, 2021. The copyright holder for this preprint (which was not certified by peer review) is the author/funder, who has granted bioRxiv a license to display the preprint in perpetuity. It is made available under aCC-BY-NC-ND 4.0 International license.

242 Figure 1. Gross symptoms of disease in Ranavirus-infected amphibians at One Shot Pond. (A-B)

243 Moribund gopher frog (Lithobates capito) tadpoles showing hemorrhages (arrows) and discoloration 244 (triangles). (C-D) Paedomorphic striped newts (Notopthalmus perstriatus) showing hemorrhage and 245 necrosis (arrows), and erythema (triangle) of the mouth.

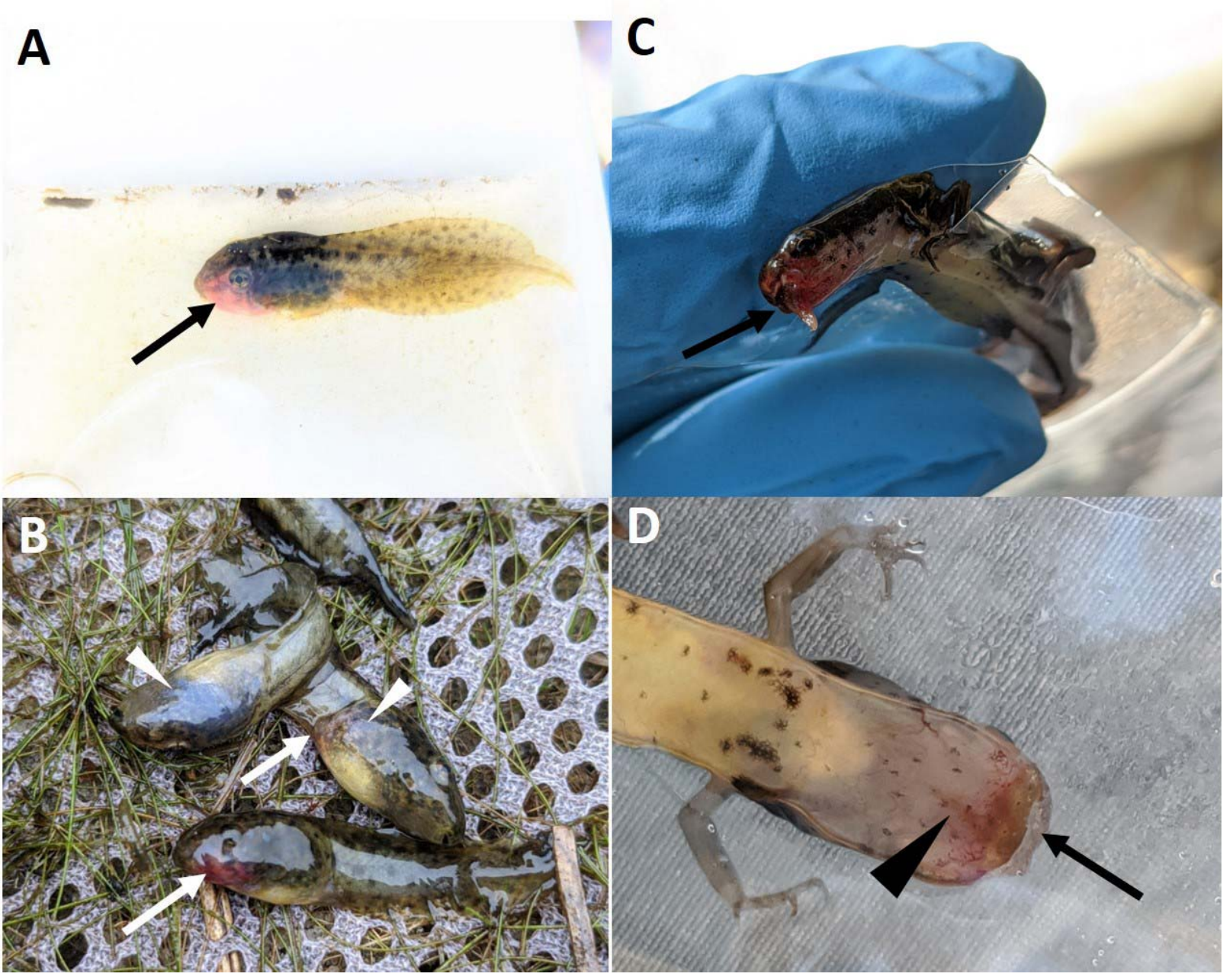


bioRxiv preprint doi: https://doi.org/10.1101/2021.1015.464511. this version posted October 15, 2021. The copyright holder for this preprint (which was not certified by peer review) is the author/funder, who has granted bioRxiv a license to display the preprint in perpetuity. It is made available under aCC-BY-NC-ND 4.0 International license.

256 Figure 2. Histologic evidence of Ranavirus infection in gopher frogs (Lithobates capito). (A) Renal 257 glomerular necrosis [Bar $=50$ microns]. (B) Splenic necrosis [Bar $=50$ microns]. (C) Cytoplasmic 258 ranaviral inclusions highlighted by black arrows [Bar $=20$ microns].

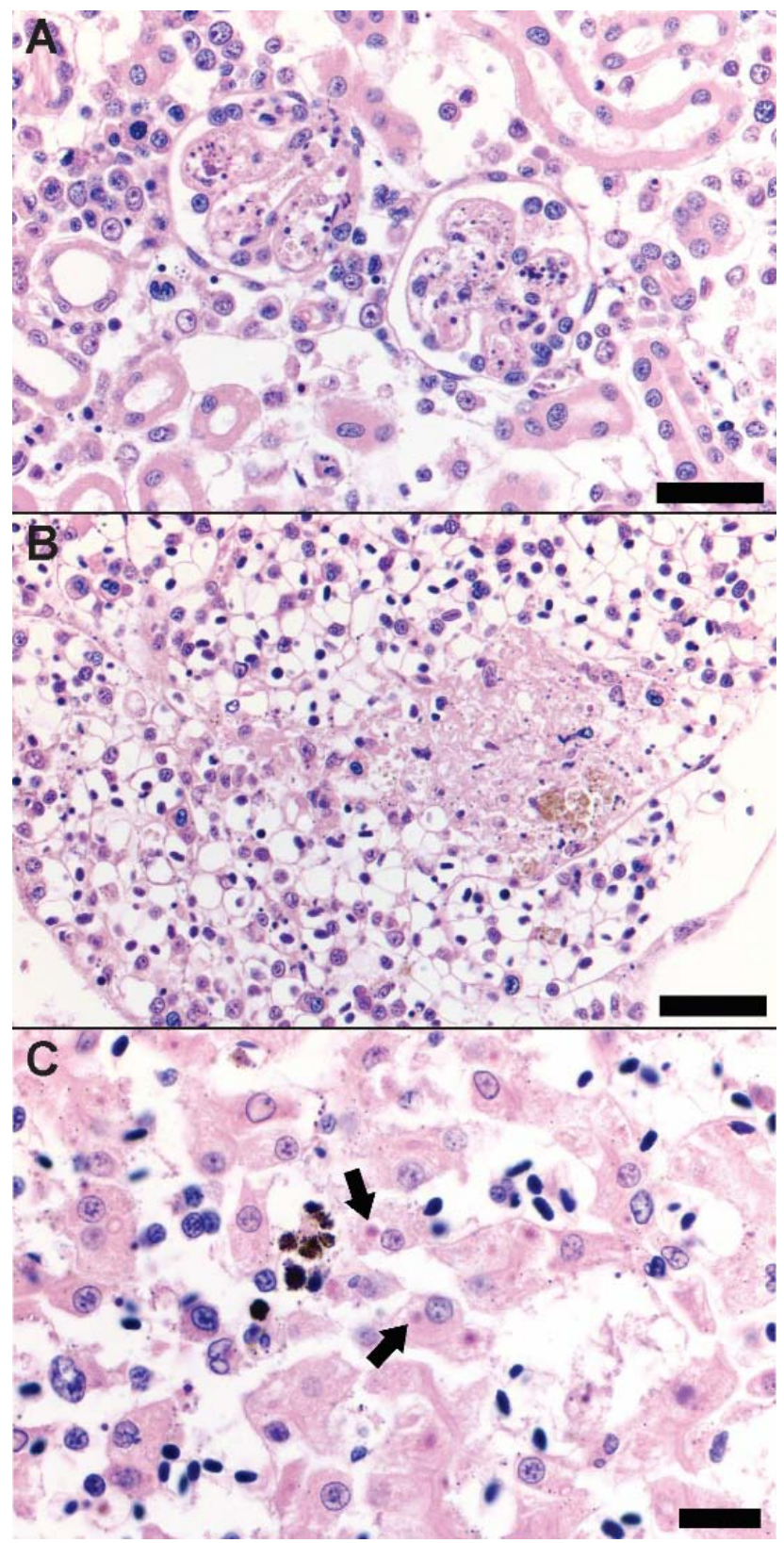


266 Figure 3. Prevalence and intensity of Ranavirus infections in three amphibian species during two

267 sampling events at One Shot Pond at the Ordway-Swisher Biological Station.

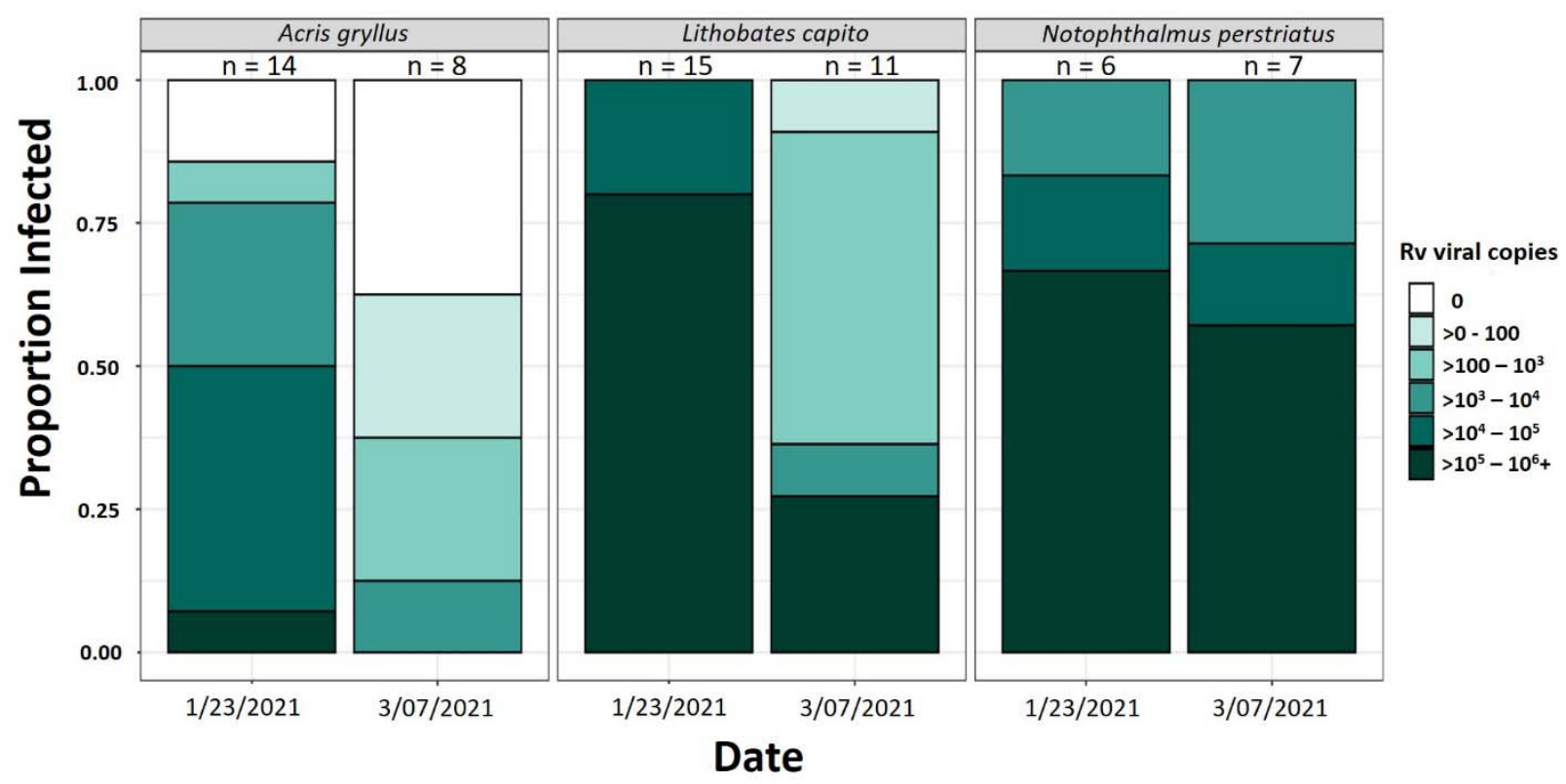

Table 1. Species, life stage $(\mathrm{A}=$ adult, $\mathrm{L}=$ larva, $\mathrm{P}=$ paedomorph, $\mathrm{MP}=$ metamorphosing paedomorph $)$ and prevalence of infection by $R v$ and $B d$ and the average $R v$ intensity combined from the two sampling events.

\begin{tabular}{|c|c|c|c|c|c|c|}
\hline Species & $\begin{array}{l}\text { Life } \\
\text { Stages } \\
\text { Detected }\end{array}$ & $\begin{array}{l}\text { Number } \\
\text { sampled }\end{array}$ & $R v+$ (Prev.) & $B d+$ (Prev.) & $\begin{array}{l}B d+/ R v+ \\
\text { (Prev.) }\end{array}$ & $\begin{array}{l}\text { Avg. } R v \\
\text { intensity (viral } \\
\text { copies) }\end{array}$ \\
\hline Acris gryllus & A & 22 & $17(77.2 \%)$ & $10(45.5 \%)$ & $9(40.9 \%)$ & 844.15 \\
\hline Lithobates capito & $\mathrm{L}$ & 26 & $26(100 \%)$ & $0(0 \%)$ & $0(0 \%)$ & $2.3 \times 10^{6}$ \\
\hline Notophthalmus perstriatus & $\mathrm{P}, \mathrm{MP}$ & 13 & $13(100 \%)$ & $0(0 \%)$ & $0(0 \%)$ & $1.2 \times 10^{6}$ \\
\hline Total & & 61 & $54 / 61(88.5 \%)$ & $10 / 61(16.4 \%)$ & 9/61 (14.8\%) & $1.3 \times 10^{6}$ \\
\hline
\end{tabular}
270 